\title{
Morocco vis-a-vis the international crisis: contribution of the economic diplomacy
}

\author{
Amine DAFIR $^{1}$, Karima HAOUDI ${ }^{2}$ \\ ${ }^{1}$ Researcher-Department of Economics and Management, Center of Doctoral Studies, Faculty of Economic \\ Sciences, University Mohammed V-Souissi, Rabat, Morocco \\ ${ }^{2}$ PhD student-Department of Economics and Management, Center of Doctoral Studies, Faculty of Economic \\ Sciences, University Mohammed V-Souissi, Rabat, Morocco
}

\begin{abstract}
Morocco is one of the developing countries occupying a strategic position nowadays. In this order, He multiplies the free trade agreements and becomes member of several international organizations. He focuses furthermore on economic diplomacy to respond to the international challenge of integration his economy into the global economy.

Morocco which faces unprecedented crisis adopts an active diplomacy aimed to diversify his partners and promotes the attractiveness of foreign investments. However, the contribution of the economic diplomacy remains low compared to the committed resources. This assessment invites us to engage an abroad reflection on the contribution of the economic diplomacy in the development of emerging countries, beyond the Moroccan case.
\end{abstract}

Key words: Economic Diplomacy, strategic intelligence, diplomacy contracts, Moroccan economy, international economy, international crisis, promotion.

\section{Introduction}

The study of the economic diplomacy takes so far more and more interest, due to the fact that an effective economic diplomacy leads the country to a situation characterized by efficient exchanges with the rest of the world, and consequently to its integration in the worldwide economy.

The ability of diplomacy to promote exports of the country, both to attract the overseas investments and to accompany the national companies in offensive policies abroad, enabled it to occupy an important place as a key factor of economic development. This economic diplomacy can be defined as "a whole practical mechanism adopted by individuals or groups, aimed to reach economic objectives by the use of political means, or achieving policy objectives through the use of economic instruments",

Within this framework, the study of the Moroccan economic diplomacy as a factor of integration into the international economy is more current and timely. Especifically, the axes of this article revolve around a central question: What is the role of the Moroccan economic diplomacy for a better insertion of the Moroccan economy into the international economy in a crisis?

\section{Review of literature}

It is important to specify within the framework of the theoretical analysis of the economic diplomacy that there is not a specific theory which can provide answers on the way in how States, in certain circumstances, will lead their policies or will define their strategies during a negotiation (Bayne and Woolcock 2011).

If there is a rich theoretical corpus analysis of foreign policy with a whole literature that attempts to explain what factors influence the choice of different strategies, theoretical studies to explain economic diplomacy are not abundant enough. In fact, as discussed by Kostecki and Naray (2007), the body of the literature on the subject is still limited. The literature "does not identify, neither explains and nor includes/understands the greatest influence of private interests in diplomacy" (Lee and Hudson 2004).

If the realistic theories ${ }^{2}$ regard the economic diplomacy as being a tool for a State enabling him to reinforce its power over other States, the neorealism differs and is characterized by taking into account interdependences, the need to strengthen the logical temporary alliances in order to build security systems. Thus,

\footnotetext{
${ }^{1}$ Amine DAFIR, « La diplomatie économique marocaine en Afrique subsaharienne : réalités et enjeux », Géoéconomie 2013 - cairn.info

${ }^{2}$ By the economist Krugman.
} 
States would seek to maintain a constant balance of forces in order to suppress the development of the power of other States considered as competitors (Lucas 2009).

The Ricardo's Theory of Comparative Advantage, which constitutes the justification of the international trade, and ultimately that of globalization, also finds its counterpart in the field of economic diplomacy (Kateb 2010). Indeed, certain form of specialization is observed in this field, according to "modi operandi" which make it possible to maximize the national competitive advantage, while reflecting the politico-administrative culture of the country, large or small, emergent or emerged, and its effective capacity to integrate the key success factors which found an optimal insertion in the world line production.

To the concept of comparative advantages comes to substitute that of competitiveness of the nations. Highly criticized by the liberal economists for his not-relevance ${ }^{3}$, nevertheless the concept was integrated by the States, to start with the United States and the European Union and the indices of its measurement, have now become essential references. In its most general definition, the concept aims at measuring the capacity of a nation to face international competition and its capacity to create the conditions likely to generate growth in a world open to international competition (Deblock 2002). Thus comes into play, upstream, all that is likely to influence the choices of the investors and attract the international investment favorably, and downstream, all that is likely to support the competitiveness of the "national" companies on the international markets. On the basis of there, more than a regulator of economic activity, the State seems a promoter, and this, in triple sens of the term, i.e. at the same time as a seller of a product, the national economic space, as a buyer of a factor of development, the international investment, and as assembler of energies, those of the nation (Michalet 1999).

However, these theories make important simplifications with regard to States like unit actors with clearly defined and stable political preferences, and it is possible to test if they are correct or not. Furthermore, it makes no sense to think that states are unitary actors, the negotiators are fully informed of national policy preferences or these preferences will be stable and not affected by changes in the market. This kind of theory does not provide a surplus in understanding the new economic diplomacy that focuses on the interaction between domestic and international factors and also between economic and political concerns in the negotiation of free trade agreements (Bayne and Woolcock 2005).

In fact, economic diplomacy is a complex area of study that is at the interstice of the national and the international policy, economics and politics, the interests of the nation and the interests of the private groups. It is subject to the influence of a growing number of variables and which requires, to be apprehended, a multidisciplinary approach as well illustrated by the specialized literature in this field.

\section{Implication of new actors}

The effective control of the economic diplomacy of the country rests largely on the capacity of its actors to control the follow-up of the multilateral and bilateral negotiations, to defend the interests of the country, to benefit from the assistance of the partners, to attract the foreign investors, to determine the business practices of the competitors and to integrate the economic diplomacy within the framework of a national device of economic intelligence. A framework which will make it possible to the various actors to reach strategic information for better benefit from various opportunities on a world level ${ }^{4}$.

Indeed, the institutional framework of the economic diplomacy is always in change to take into account the emergence of new actors and new missions. Consequently, the number of actors who contribute to the development and the implementation of the economic diplomacy is increased considerably.

The list of ministries, agencies and organizations which, within the administration, convergent with the development of the economic diplomacy and its implementation is impressive. More still, the MAEC (Ministry for Foreign Affairs and of Co-operation) and the MCE (Ministry for Foreign trade) occupy the leading roles. Structures like the CNCE (National council of the foreign trade) or the AMCI (Moroccan Agency of International cooperation) are also actors privileged in the field of negotiation of trade agreements or the implementation of policy of development assistance. Other ministries like Agriculture, Health or Industry, have in their center services whose role deserves to be underlined. Lastly, the inclusion of questions like the rules of origin or the intellectual property in the diary of the international trade negotiations mobilized new actors such the $\mathrm{ADII}^{5}$.

The role of the representatives of Morocco abroad, namely the diplomatic personnel in station in the embassies or near the international organizations, is not limited to put forward the position of Morocco near

\footnotetext{
${ }^{3}$ The Global Competitiveness Report and the World Competitiveness Report for example.

${ }^{4}$ Jaïdi. http://www.lavieeco.com/news/debat-et-chroniques/les-defis-de-la-diplomatie-economique-15432.html consulté le 10/02/2013.

${ }^{5}$ Administration of customs and excises.
} 
their interlocutors, to collect their position and to inform the MAEC of them. They also intervene as being representatives of the Moroccan private sector and defend the economic interests of the country. Also, all the government and non-governmental organizations (NGO) which have economic responsibilities and operate with the international level are engaged in the economic diplomacy. Each organization tries to exert its influence on the development process and strategic decision making of the country. The decision is thus the result of an interaction between many actors influenced by a complex environment.

The Agencies of Promotion of the Investments and Exports represent the actors having for mission the promotion of "Morocco product" as a destination and a product with export, through the implementation of the strategic directions of the country as regards foreign economic policy. The Moroccan Agency of development of investments (AMDI) was elected, in London, better Agency of promotion of direct foreign investments (DFI) of the area "MENA" (Middle East and North Africa) to the title of the year 2013 by the magazine6 "The European"7. Moreover, the AMDI received the price Euromediterraneo 2013 in Rome under its communication campaign on television, the written press and the digital one, placed under the slogan "Morocco, more Business". This price, sponsored by Confindustria Assafrica \& Méditerraneo and Association Italian of the Sectors Public and Institutional, beyond the quality and from the relevance of the publicity campaign, comes to crown the work completed by the representative office of the AMDI in Rome in collaboration with the embassy of Morocco in Italy, near the Italian institutional prescribers ${ }^{8}$.

Lastly, the role of the private economic agents should not be omitted. Whether it's the private sector, but also professional associations, think tanks, NGOs, all work on the one hand, as pressure groups which attempt to influence policy makers so that their interests are taken into account by economic diplomacy implemented by the country. And on the other share, they act as autonomous actors defending the economic interests of the country and ensuring the promotion of the brand image of the national product.

Nevertheless, an examination ${ }^{9}$ of the components of the institutional framework of the economic promotion of Morocco abroad was carried out by the Ministry for the Foreign trade through the analysis of convergences and divergences of their legal and effective missions and of the quality of human and financial resources they have. This work was supplemented by a benchmarking of the experiments of competitor countries and put forward what follows:

$>\quad$ multitude of speakers of the Moroccan institutional framework of economic promotion abroad;

$>\quad$ the weakness of the human and financial means;

$>\quad$ and lack of coordination among its components.

All in all, the institutional framework of the economic diplomacy must know a complete change of its operating processes, of its sphere of activity, in its decision-making processes and the width of its means of action. This also implies that there is a communication within the issues of diplomacy influence.

\section{Emergence of a diplomacy of the contracts}

Sign that the economy was essential like a major field of the diplomatic activity, rare are today the official visits of Heads of State who do not integrate in their delegations leaders of large companies, representatives of the private sector, contractors and various persons in charge.

There' is not a precise definition of the diplomacy of the contracts. Moreover, in spite of the importance and the stakes of such a diplomacy, little works treat this question. She is regarded as being a form of the diplomacy economic, generally State diplomacy, aiming at guaranteeing to public or private enterprises markets or great contracts without going through tenders. Its purpose is to support businesses and the defense of national products. Its tools are generally a direct intervention of Head of State or one of its advisers or during an official visit integrating entrepreneurs and business leaders. The stakes are very important; we usually talk about contracts of billion dollars for fairly long periods. Moreover, it is obvious, in particular for the developing countries, that for the financially important contracts (planes, TGV, subways...), the political considerations

\footnotetext{
6 "The European" is a British specialist journal, a subsidiary of Chase Publishing, which is addressed by a team of experts and experienced analysts, business and C-levels across the world leaders.

${ }^{7}$ http://www.lemag.ma/Relative-bonne-nouvelle-pour-I-economie-marocaine-Les-IDE-reprennent_a71160.html_consulted in $15 / 08 / 2013$.

${ }^{8} \mathrm{http}: / /$ www.leseco.ma/dernieres-minute/14676-investissement-le-maroc-seduit-en-italie\#.UjCCA9LmOw1_consulted in $18 / 06 / 2013$.

${ }^{9}$ Ministère du Commerce Extérieur, Diagnostic et éléments pour une nouvelle stratégie du commerce extérieur, Octobre 2006.
} 
return in account in the exit of the choice in a decisive way ${ }^{10}$. This confrontation between the political and economic objectives makes the study of the diplomacy of contracts a hard exercise for the analysts. Is added to that, The non-visibility of the hidden face of the agreement on the contract. This is what sometimes explains the different readings of a decision to grant a specific contract to a particular country.

Thus, the official delegations involve a promotion appropriateness of exports and investments. This diplomacy of the contracts led by Heads of State of developed countries testifies to the importance of the relative position of each country in the commercial relations ${ }^{11}$.

However, it is necessary to distinguish an official visit from a foreign delegation in Morocco and an official visit of a Moroccan delegation to a foreign country. The policy issues behind concluding contracts to the profit of companies of the country are generally related to a political support in a given file. It would just be enough to see the quality of the French TGV which requires new rails and thus an additional cost and its German equivalent the ICE ${ }^{12}$ which rolls on slightly improved simple rails and less expensive, to understand at which point the French companies are privileged compared to the other countries ${ }^{13}$.

There remains the Moroccan diplomacy must juggle his business and political interests, a task that is sometimes very difficult. However, if the objectives of economic development are an important issue for the Moroccan economic diplomacy, they are not always the only reason. The political stakes are usually put forward to explain the aggressive diplomacy of contracts adopted by France and the United States.

The last visit of King Mohammed VI to the countries of the gulf is part of a trend of protecting the economic interests of the country. Several contracts and projects will be financed by local entrepreneurs. The leaders of the Cooperation Council of Gulf (CCG) agreed to grant Morocco a loan of 5 billion dollars. In addition, the royal visits in sub-Saharan Africa know are increasingly greater and know the participation of Moroccan entrepreneurs wishing to internationalize and export to Africa. Moreover, tens of Moroccan enterprises, considered as being "national champions" have found a place among the great African investors in the continent ${ }^{14}$ and the current challenge of the Moroccan economic diplomacy is to accompany internationalization of Moroccan SMEs.

\section{Conclusion}

In the context of crisis that the world knows and to better benefit from the opportunities offered by the panoply of signed agreements, Morocco has a proactive policy aimed at promoting the image of the country through the establishment of a number of institutions and the promotion of bilateral and multilateral cooperation. Nevertheless, Morocco does not take advantage from the various actions of its economic diplomacy. In terms of export promotion and attraction of foreign investment, constituting the basic elements in any development strategy, the contribution of the Moroccan economic diplomacy remains very weak.

Thus, Morocco seeks to re-examine its sales strategy to make it more aggressive by integrating its economic diplomacy in a national economic intelligence system. Moreover, this is why the economy has become a priority of the Moroccan diplomacy.

Nevertheless, the diplomacy is downstream in the chain. So, it does nothing but reflect the decisions taken inside the country. Because to be competitive, it is also necessary to take care on the capacities of research and innovation, the robustness of the production system, the quality of the universities and the research centers, the power of logistics...

Finally, it is essential to promote an economic diplomacy able to let foresee a solution to structural problems of Moroccan economy and to the current imbalance of the macroeconomic indicators, which may weigh heavily in the coming years and reposition Morocco on the world economic chart.

${ }^{10}$ Frédéric PEDEMAS, Les échanges internationaux de marchandises obéissent-ils aux principes du libre échange ? Février 2000.

${ }^{11}$ Gagnants ou perdants du commerce mondial : impact de l'ouverture commerciale sur la vulnérabilité de l'emploi par Adama Zerbo.

12 The Intercity-Express.

${ }^{13}$ http://www.bigbrother.ma/2010/07/le-gouv-francais-sattaque-aux-centres.html consulted in 03/06/2013.

${ }^{14}$ Amine DAFIR, "La diplomatie économique marocaine en Afrique subsaharienne : réalités et enjeux ", Géoéconomie 2013 - cairn.info 


\section{References}

[1]. A. Dafir, « La diplomatie économique marocaine en Afrique subsaharienne : réalités et enjeux », Géoéconomie 2013.

[2]. Diane Stone et Mark Garnett. «Think Tanks across nations : a comparative approach». Manchester University Press, 1998.

[3]. Audrey Knauf, Les dispositifs d'intelligence économique: Compétences et fonctions utiles à leur pilotage- Business intelligence 2010.

[4]. Harold Wilensky, " Organizational Intelligence: Knowledge and Policy in Government and Industry" 1967.

[5]. Gilpin, R. Global Political Economy: Understanding the International Economic Order. New Jersey: Princeton University Press. 2001.

[6]. Guy Carron de la Carrière « La diplomatie économique, le diplomate et le marché »; édition Economica, 1998.

[7]. Nicholas Bayne \& Stephen Woolcock, The New Economic Diplomacy. Decision-Making and Negotiation in International Economic Relations. Bayne. Hampshire, Ashgate Publishing, 2003.

[8]. McGann J. \& Weaver, R. K, (2000) Think Tank \& Civil Societies, catalysts for Ideas And Action, Transaction Publishers, London

[9]. P. Conesa «L'intelligence économique et stratégique : la diplomatie d'influence au service de la guerre économique », Revue internationale et stratégique 4/2003 ( $\left.{ }^{\circ} 52\right)$, p. 153-160.

[10]. Alexandre Mercier. Commercial Diplomacy in Advanced Industrial States: Canada; the UK, and the US. 2007. 